\title{
Az állkapocsízületi károsodás kezelése szteroiddal, illetve hialuronsavval
}

\author{
Vingender Szonja dr. ${ }^{1}$ - Restár László dr. ${ }^{2}$ - Csomó Krisztián Benedek dr. ${ }^{3}$ \\ Schmidt Péter dr. ${ }^{2}$ - Hermann Péter $d r^{2}$ - Vaszilkó Mihály dr. ${ }^{1}$ \\ Semmelweis Egyetem, Fogorvostudományi Kar, ${ }^{1}$ Arc-, Állcsont-, Szájsebészeti és Fogászati Klinika, \\ ${ }^{2}$ Fogpótlástani Klinika, ${ }^{3}$ Orális Diagnosztikai Tanszék, Budapest
}

Bevezetés: Az állkapocsízületi károsodás nehezen felismerhető népbetegség, mely a folyamatosan fennálló fej- és arcfájdalom, illetve a rágófunkció zavara miatt a betegek mindennapi életét nehezíti meg. Terápiája sokrétü, több társszakma együttmúködését igényli. A kezelési sorrend első lépcsője a konzervatív terápia; ennek hatástalansága esetén minimálinvazív beavatkozáshoz, azaz intraarticularis terápiához folyamodunk, melyben egyre nagyobb hangsúlyt kap a hialuronsav alkalmazása.

Célkitüzés: Kutatásunk célja volt összehasonlítani az intraarticularis hialuronsavnak és a kortikoszteroidinjekciónak az állkapocsízületre gyakorolt hatását. Vizsgáltuk ezenfelül a hialuronsavas kezelés esetén a molekulasúly és az adagolás gyakoriságának kérdését.

Módszer: 37, intraarticularisan, szteroiddal vagy hialuronsavval kezelt ízület gyógyítási eredményeit hasonlítottuk össze. Preoperatívan meghatároztuk a klinikai és a radiológiai (MR-felvétel) adatok alapján az ízületi károsodást jól mutató Wilkes-stádiumot, a szájnyitás mértékét és a betegek szubjektív fájdalomintenzitását reprezentáló Visual Analogue Scale-t, majd ugyanezen vizsgálatokat 6 hónap múlva megismételtük. Kortikoszteroidot egy alkalommal adtunk, míg hialuronsavat heti egyszer, egymást követő 3 alkalommal, alacsony $\left(6-10 \times 10^{5}\right.$ dalton) vagy magas molekulasúlyú (24-36 × 105 dalton) anyagot alkalmazva.

Eredmények: A szteroidinjekció után a betegek állapota átmeneti posztoperatív javulást mutatott, később viszont a tünetek recidiváltak. A hialuronsavas kezelés hatására mindhárom vizsgált paraméter szignifikánsan javult a preoperatív értékekhez képest $\left(\mathrm{p}_{\text {wilkes }}<0,0001 ; \mathrm{p}_{\text {szájnyitás }}=0,0002 ; \mathrm{p}_{\mathrm{VAS}}<0,0001\right)$; a recidíva nem volt jelentős $(\mathrm{T}=2,05)$. A háromszori adagolás szignifikáns fájdalomredukciót eredményezett az első, illetve a második injekció hatásával összehasonlítva $\left(\mathrm{T}_{3 .-1 .}=20,37 ; \mathrm{T}_{3 .-2 .}=9,57\right)$.

Következtetés: A két anyagot összehasonlítva megállapíthatjuk a hialuronsav szignifikánsan nagyobb eredményességét, illetve a háromszori alkalmazás hatásosságát. A nagyobb molekulasúlyú változat csak a szájnyitás mértékének javításában volt hatékonyabb, de az eltérés nem volt szignifikáns. A hialuronsav minden Wilkes-stádiumban hatékonynak bizonyult, a szteroid viszont a magasabb stádiumban tartós hatást nem fejtett ki.

Orv Hetil. 2018; 159(36): 1475-1482.

Kulcsszavak: temporomandibularis ízület, kortikoszteroid, hialuronsav, molekulasúly

\section{Intra-articular steroid and hyaluronic acid treatment of internal derangement of the temporomandibular joint}

Introduction: Derangement of the temporomandibular joint complicates everyday life, due to the masticatory malfunction and the continuous pain sensation of the head and facial region. The therapy is multidisciplinary and varying. In case of the inefficiency of conservative therapy, minimally invasive intervention is needed with intraarticular injection.

Aim: The aim of our study was to examine whether hyaluronic acid injection is more beneficial compared to corticosteroid in 37 joints. We also examined whether the efficacy of the therapy is influenced by hyaluronic acid molecular weight and the used protocol.

Method: Wilkes stage, maximal mouth opening and the Visual Analogue Scale were determined pre-operatively and 6 months later. Corticosteroid application was performed once, hyaluronic acid was injected on a weekly bases 3 times in a row, by use of low $\left(6-10 \times 10^{5}\right.$ dalton $)$ or high molecular weight $\left(24-36 \times 10^{5}\right.$ dalton $)$ preparations.

Results: The medical state of the patients treated with corticosteroid temporarily improved, but the symptoms returned. Due to hyaluronic acid treatment, significant improvement was revealed in all parameters $\left(\mathrm{p}_{\text {wilkes }}<0.0001\right.$; $\left.\mathrm{p}_{\text {mouth-opening }}=0.0002 ; \mathrm{p}_{\mathrm{VAS}}<0.0001\right)$. There was no significant relapse $(\mathrm{T}=2.05)$. The third administration of hyalu- 
ronic acid resulted in a significant improvement of the Visual Analogue Scale compared to the first and second injection $\left(\mathrm{T}_{3 .-1 .}=20.37 ; \mathrm{T}_{3 .-2 .}=9.57\right)$.

Conclusions: Comparing the two agents we can state that hyaluronic acid was significantly more effective and its application for three times seems to be the most effective treatment decreasing the symptoms. The high molecular weight solution was more effective in increasing mouth opening. In contrast to hyaluronic acid, corticosteroid had no prolonged effect in higher Wilkes stages.

Keywords: temporomandibular joint, corticosteroid, hyaluronic acid, molecular weight

Vingender Sz, Restár L, Csomó KB, Schmidt P, Hermann P, Vaszilkó M. [Intra-articular steroid and hyaluronic acid treatment of internal derangement of the temporomandibular joint]. Orv Hetil. 2018; 159(36): 1475-1482.

(Beérkezett: 2018. március 27.; elfogadva: 2018. május 9.)

\section{Rövidítések}

ANOVA $=($ analysis of variance $)$ varianciaanalízis; $\mathrm{HA}=($ hyaluronic acid) hialuronsav; $\mathrm{MR}=$ (magnetic resonance) mágneses rezonancia; $\mathrm{RA}=$ (rheumatoid arthritis) sokízületi gyulladás; $\mathrm{RDC} / \mathrm{TMD}=$ (research diagnostic criteria for temporomandibular diseases) a rágóízületi elváltozások diagnosztikájának módszere; TMD = temporomandibular disorders-nek nevezett kórkép; TMI = temporomandibularis ízület; VAS = (Visual Analogue Scale) Vizuális Analóg Skála

Az állkapocsízületi (TMI-) károsodás olyan multifaktoriális rágószervrendszeri elváltozás, amely a krónikus arcfájdalom és az ízületi mozgászavar egyik fő okozója lehet. A betegség felismerése és kezelése régóta általános probléma mind a fogorvoshoz, mind a neurológiai jellegú panaszokkal általános orvoshoz forduló betegek körében. Fontosnak tartjuk tehát a TMI-diszfunkció kialakulásának hátterében álló okok tisztázását és a társszakmák együttmúködésén alapuló megfelelő oki terápiát.

Egyes kutatók szerint a normálpopulációban az ízületi eltérések (például hangjelenség) prevalenciája 75\%-os, míg a betegség legalább egy tünete (például ízületi fájdalom) 33\%-ban fordul elő [1]. Egy Magyarországon végzett felmérés a populáció 50-75\%-ában mutatott TMIdiszfunkcióra utaló elváltozást, a kezelésre szorulók aránya $3-7 \%$. A nók négyszer nagyobb gyakorisággal érintettek a kórképben, mint a férfiak [2].

A kórkép az egyéb degeneratív ízületi elváltozásokkal ellentétben az idősek mellett a fiatalokat is érinti [3]. Diagnosztikai, prognosztikai és terápiás szempontból is igen tisztázatlan terület [4]. Az ízület károsodása abnormális kapcsolatot jelent a discus, a condylus és az eminentia articularis között [5], mikro- vagy makrotrauma után kialakuló, MR-vizsgálattal kimutatható elváltozás [6]. A belső károsodás kialakulása krónikus parafunkcióhoz is köthető, mely az ízfelszínek degeneratív elváltozásához vezethet [7].

A kórképnek számos elnevezése terjedt el az irodalomban. Elsőként Costen 1934-ben fülfájással, fülzúgással, fejfájással, trismussal és csökkent hallással járó kórképet írt le, amelyet Costen-szindrómának neveztek [8]. A ma legtöbbször használt, TMI-diszfunkciónak vagy a külföldi irodalomban „temporomandibular disorders”-nek nevezett kórkép (TMD) általánosan használt fogalom bárminemú problémára, amely érinti a rágóapparátust.

Az ízület belső károsodásának kialakulásában több tényező is szerepet játszhat, anatómiai faktorok, az ízület túlterhelése, pszichoszociális tényezők, genetikai és metabolikus faktorok, illetve sérülések, fizikai traumák. A páciensek által leggyakrabban említett tünet az egyoldali arcfájdalom, amely kisugározhat a temporalis vagy periorbitalis régióba, a mandibulaszöglethez, illetve gyakran a nyak hátsó részébe. A fájdalom általában tompa, állandó jellegú, amely a nap bizonyos szakaszaiban rosszabbodhat. Jellemző panasz továbbá az állkapocsízületi mozgások beszúkülése, az ízület „beakadása” a száj nyitott vagy zárt állapotában, az ízületi hangjelenségek, mint a kattogás vagy a crepitatio.

A betegség kezelése multidiszciplináris és összetett feladat. A konzervatív kezelés részét képezi a farmakoterápia, a fogászati kezelések, a dezorientációs sín használata, a fizio- és fizikoterápia. E módszerek gyakran nagyobb költséggel járnak a beteg számára, és a betegség nem minden formájában hatásosak. Amennyiben a súlyos tünetek nem enyhülnek a konzervatív terápiát követően, sebészi konzultáció javasolt [9]. A sebészi megoldások (artroszkópia, nyílt sebészi feltárás) azonfelül, hogy szintén költségesek, megterhelők a szervezet számára, és szövődményekkel járhatnak, az eredmény pedig nem minden esetben garantált.

A konzervatív és sebészi beavatkozások előnyeit egyesíti és hátrányait küszöböli ki a minimálinvazív intraarticularis befecskendezéses kezelés, melynek ma a leggyakrabban használt anyaga a szteroid és a hialuronsav. A szteroidot már közel 50 éve használják ízületi lokális kezelésnél, míg a hialuronsav újabban, az utóbbi években került a figyelem középpontjába. Az intraarticularis kortikoszteroidterápiában az egyszeri, illetve a 14 nap eltéréssel kétszeri protokoll terjedt el. Toller ajánlása 
alapján a potenciálisan előforduló szövődmények miatt nem javasolt az állkapocsízületbe történő kétszeri injektálás. Az intraarticularis hialuronsavas terápiát tekintve nincs egységes álláspont a molekulasúly kérdésében és az alkalmazás protokolljában. Egyes szerzők az egyszeri, arthrocentesissel kiegészített vagy a nélküli hialuronsavas injekció protokollját alkalmazzák [10], mások a 7 vagy 14 napos eltéréssel beadott kétszeri injekciót $[11,12]$. Basterzi a három alkalommal, heti egyszer beadott injekció protokollját követi [13], Sato pedig az ötször alkalmazott, heti egyszeri terápiát követi [14]. Kutatásunkban összehasonlítottuk az egyszeri kortikoszteroid és a 3 hétig tartó, heti egyszeri, alacsony, illetve magas molekulasúlyú hialuronsavas injekció hatását.

Vizsgálatunkban arra kerestük a választ, hogy az intraarticularis kezelések során a szteroidhoz képest a hialuronsav rövid és hosszabb távon eredményesebb hatást mutat-e az ízületi funkció és a fájdalom javításában. Vizsgáltuk továbbá, hogy a hialuronsavas kezelésen belül az anyag molekulasúlya és az alkalmazási protokoll befolyásolja-e a terápia eredményességét.

\section{Módszer}

A kutatást az Egészségügyi Tudományos Tanács Tudományos és Kutatásetikai Bizottsága engedélyezte (engedélyszám: BPR/021/01566-2/2015).

Prospektív vizsgálatunkban a Semmelweis Egyetem Arc-, Állcsont-, Szájsebészeti és Fogászati Klinikáján 24 beteg 37, MR-felvétellel igazoltan károsodott ízületét kezeltük. Az MR-vizsgálat minden esetben porcsérülést detektált, a discus folytonossághiányát, a hialinporc borításának károsodását, subchondralis degenerációt vagy a porckorong diszlokációját írta le. A páciensek bevonása az RDC/TMD kritériumok szerint történt: azok kerültek be a vizsgálatba, akik a Semmelweis Egyetem Fogpótlástani Klinikáján konzervatív kezelésen átestek (gnatológiai, fizioterápiás kezelés), de maradék tüneteik további ellátást igényeltek. A csupán izomeredetű hátterü fájdalommal rendelkező betegek (myofascialis szindróma) kizárásra kerültek. Egyéb szelekciós alap nem volt.

A betegek nemre való tekintet nélkül, 18-80 éves kor között kerültek beválasztásra, MR- és fizikai vizsgálattal igazolt TMI-elváltozásokkal.

A krónikus TMI-diszfunkció tüneti kezelését tehát intraarticularis szteroiddal, illetve hialuronsavval végeztük. A két csoport közti elosztást időbeli randomizáció jelentette: 2013 áprilisától 2013 októberéig kortikoszteroidot, 2013 októberétől 2014 márciusáig alacsony molekulasúlyú hialuronsavat, 2014 áprilisától 2014 szeptemberéig magas molekulasúlyú hialuronsavat injektáltunk.

A preoperatív vizsgálatokban statikus és mozgó MRfelvételek készültek. A vizsgálatok során a szájnyitási korlátozottság mértékét mértük milliméterben az interincisalis területen. A szubjektív panaszokat Vizuális Analóg
Skálán (Visual Analogue Scale - VAS) értékeltük, melynek során a beteg 0-tól 10-ig terjedő skálán határozza meg az érzett fájdalom szintjét. A „0” a panaszmentességet, a „10” a legerősebb fájdalmat jelöli. A radiológiai jelek és a klinikai tünetek alapján meghatároztuk a Wilkes-stádiumot, amely a belső károsodás mértékén alapuló osztályozás. A belső károsodás kiterjedése 5 stádiumba sorolható, amely magában foglalja az osteoarthritis stádiumait is [15].

A betegeket két csoportba osztottuk attól függően, hogy intraarticularisan szteroid- ( $\mathrm{S}$ csoport, $\mathrm{n}=7$ ), vagy hialuronsav- ( $\mathrm{H}$ csoport, $\mathrm{n}=17$ ) injekciót kaptak. Alacsonyabb molekulasúlyú (0,6-1 millió dalton) oldatot 6 páciens kapott, 11 beteg pedig magasabb molekulasúlyút (2,4-3,6 millió dalton), válogatási alap nélkül.

A beszúrási pont helyét és környékét minden esetben lokálisan Cutasepttel fertőtlenítjük, és steril körülmények között a processus condylarist kitapintjuk. 19 G túvel $0,5 \mathrm{ml}$ érzéstelenítőt (lidokain/adrenalin 20 $\mathrm{mg} / 0,01 \mathrm{mg} / \mathrm{ml}$ ) injektálunk subcutan és a tok elérzéstelenítésére az ízületbe is. Leírás szerint a beszúrási pont 2 mm-rel a külső szemzugot a tragussal összekötő vonal alatt helyezkedik el, a tragustól $10 \mathrm{~mm}$-re előrefelé. A kortikoszteroidos injekció protokollját Toller kutatásai alapján alkalmaztuk: lavage-t végeztünk, majd $1 \mathrm{ml}$ Diprophos oldatot $(2,63 \mathrm{mg}$ betametazon-nátriumfoszfát és $6,43 \mathrm{mg}$ betametazon-dipropionát/1 ml) injektáltunk az ízület felső kompartmentjébe [16]. Hialuronsavas kezelés során azonos módszerrel, három alkalommal heti egyszeri $1 \mathrm{ml}$ hialuronsav-oldatot adtunk Basterzi ajánlása alapján [13]. A beszúrási pontra mindkét kezelést követően steril gézből nyomókötést helyeztünk.

Posztoperatív kontrollvizsgálatot a kezelés után 1 héttel és 6 hónappal végeztünk, melyek során ismét megmértük a szájnyitás nagyságát, jegyeztük a fájdalom intenzitását VAS skálán. A betegek Wilkes-stádiumát és szájnyitási mértékét a 6 hónapos kontrollvizsgálaton regisztráltuk. 5 páciens esetében 12 hónappal a kezelés után is végeztünk kontrollvizsgálatot.

Az intraarticularis terápiát megelőző konzervatív kezelés egyes elemei - úgymint harapásemelő sín viselése, gyógytorna - az ízületi befecskendezést követően is kiegészítő hatással bírtak, és hozzájárultak a fájdalom csökkentéséhez és a funkció javításához.

A statisztikai elemzést ROPtat-programmal végeztük. $\mathrm{Az}$ analízis során Wilcoxon-, Mann-Whitney-U-, ANOVA-tesztet alkalmaztunk, post hoc vizsgálatként Tukey-tesztet. A Wilcoxon-, nem paraméteres tesztet a nem normál eloszlású minták teszteléséhez alkalmaztuk, a Mann-Whitney-U-, szintén nem paraméteres tesztet a nem normál eloszlású minták független elemzéséhez, az ANOVA-tesztet normál eloszlású minták teszteléséhez használtuk. A Tukey-teszttel a csoporton belüli eltéréseket vizsgáltuk. Szignifikánsnak fogadtuk el a p<0,05 értéket. 
1. táblázat |A vizsgált paraméterek átlagos változása a kiváltó tényezők függvényében

\begin{tabular}{|c|c|c|c|c|c|c|}
\hline Kiváltó tényező & $\begin{array}{l}\text { Wilkes-stádium } \\
\text { (S csoport) }\end{array}$ & $\begin{array}{l}\text { Wilkes-stádium } \\
\text { (H csoport) }\end{array}$ & $\begin{array}{l}\text { Szájnyitás }[\mathrm{mm}] \\
\text { (S csoport) }\end{array}$ & $\begin{array}{l}\text { Szájnyitás [mm] } \\
\text { (H csoport) }\end{array}$ & $\begin{array}{l}\text { VAS skála } \\
\text { (S csoport) }\end{array}$ & $\begin{array}{l}\text { VAS skála } \\
\text { (H csoport) }\end{array}$ \\
\hline RA & 0 & +2 & 0 & +10 & -4 & -7 \\
\hline Trauma & 0 & $+1,5$ & +3 & +10 & 0 & $-4,5$ \\
\hline $\begin{array}{l}\text { Bruxismus/rossz fogpótlás/harapási } \\
\text { rendellenesség }\end{array}$ & $+0,5$ & $+1,5$ & +10 & +8 & $-0,5$ & $-4,5$ \\
\hline
\end{tabular}

$\mathrm{H}$ csoport $=$ hialuronsavval kezelt csoport; $\mathrm{RA}=$ (rheumatoid arthritis) sokízületi gyulladás; $\mathrm{S}$ csoport = szteroiddal kezelt csoport; VAS $=$ Vizuális Analóg Skála

\section{Eredmények}

A 24 kezelt páciens (22 nő, 2 férfi) átlagéletkora 46 év (16-79 év), az S csoporté 40 év, a H csoporté 47 év volt. A betegek $91,6 \%$-a $(22 / 24)$ nő volt.

$\mathrm{Az}$ ízületi károsodás kiváltó okaként 2 esetben rheumatoid arthritis, 5 betegnél bruxismus, illetve clenching, 3 páciensnél a mandibulát, illetve az ízületet közvetlenül érő trauma szerepelt; 3 betegnél a tünetek hátterében a rossz kivehető fogpótlás volt a felelős, 3 esetben pedig harapási rendellenesség, fogazati eltérés miatt jött létre elváltozás. 6 páciensnél nem ismert az eredeti kiváltó tényező. A kiváltó okok szerint vizsgáltuk a kezelés eredményességét, három csoportot hoztunk létre (1. táblázat). A Wilkes-stádiumot vizsgálva a hialuronsav mindegyik csoportban hatékonyabbnak bizonyult a szteroidnál, a rehumatoid arthritises esetekben a legnagyobb különbséggel. A szájnyitás javulásának tekintetében a szteroid csak a bruxismuscsoportban mutatott hasonlóan jó hatásfokot, mint a hialuronsav. A VAS vizsgálatakor a hialuronsav mindhárom csoportban eredményesebbnek bizonyult. Az alacsony esetszám miatt azonban a statisztikai analízis csupán iránymutató.

A Wilkes-stádium tekintetében a 6 hónapos kontroll során a szteroidcsoport eredményei nem mutattak szignifikáns javulást $(\mathrm{p}(\mathrm{S})=0,2500)$, ezzel szemben a hialuronsavval kezelteké igen $(\mathrm{p}(\mathrm{H})<0,0001$, Wilcoxon-teszt) (1. ábra). A Wilkes-stádium alapján enyhe és súlyos csoportba osztályoztuk a betegeket. Enyhének az I-III. Wilkes-stádiumot tekintettük, mely 19 esetben fordult elő. Az 6, szteroiddal és 13 hialuronsavval történő betegkezelés után a medián javulás 1 volt. Hialuronsavas kezelés esetében a medián javulás 1,5 , szteroidnál 1 volt. Súlyosabb állapotnak a Wilkes szerinti IV-V. stádiumot fogadtuk el, itt 4 esetben kezeltünk hialuronsavval (medián javulás 2), l esetben pedig szteroiddal, ahol nem történt változás (2. ábra).

A hialuronsav szignifikánsan javított a szájnyitás mértékén $(\mathrm{p}(\mathrm{H})=0,0002)$. A szteroidkezelés hatására szintén javulást tapasztaltunk, de ennek mértéke nem volt szignifikáns $(\mathrm{p}(\mathrm{S})=0,1250)$ (3. ábra).

$\mathrm{Az}$ alacsonyabb molekulasúlyú hialuronsav használatakor az átlagos javulás a szájnyitás mértékében $6,6 \mathrm{~mm}$, a VAS skálán 6,5-ös érték volt, míg a magasabb molekulasúlyú hialuronsav esetében $8,4 \mathrm{~mm}$ és 5,1 volt a kapott eredmény (3. és 4. ábra).

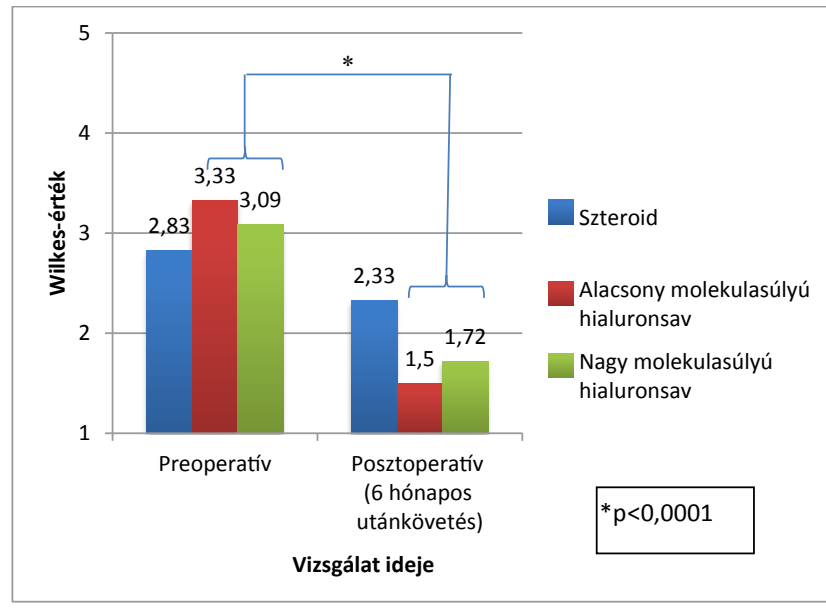

l. ábra $\quad$ A különböző intraarticularisan alkalmazott anyagok hatása a Wilkes-stádium változására

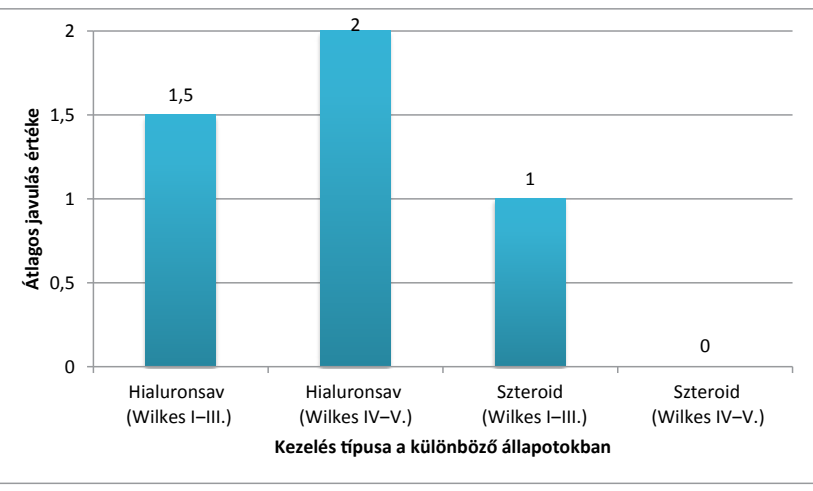

2. ábra A Wilkes-stádium változása a kezelés típusa és a kezdeti állapotok függvényében

A panaszok szubjektív megítélésében (VAS) szignifikáns különbség mutatkozott a pre- és posztoperatív, illetve a 6 hónapos status között a $\mathrm{H}$ csoportban $(\mathrm{p}(\mathrm{H})<0,0001$, ANOVA), míg az $\mathrm{S}$ csoportban szintén mutatkozott különbség, de nem szignifikáns $(\mathrm{p}(\mathrm{S})=$ 0,1817). A H csoportban Tukey-féle post hoc tesztet (páronkénti összehasonlítás) alkalmazva szignifikáns különbség mutatkozott a pre- és posztoperatív, illetve a preoperatív és a recidívaértékek között (Tpre-post $=$ $18,9$, Tpre-rec $=12,85)$. A posztoperatív és a recidívaértékek között nem találtunk szignifikáns különbséget (Tpost-rec $=2,05)$ (4. ábra). 


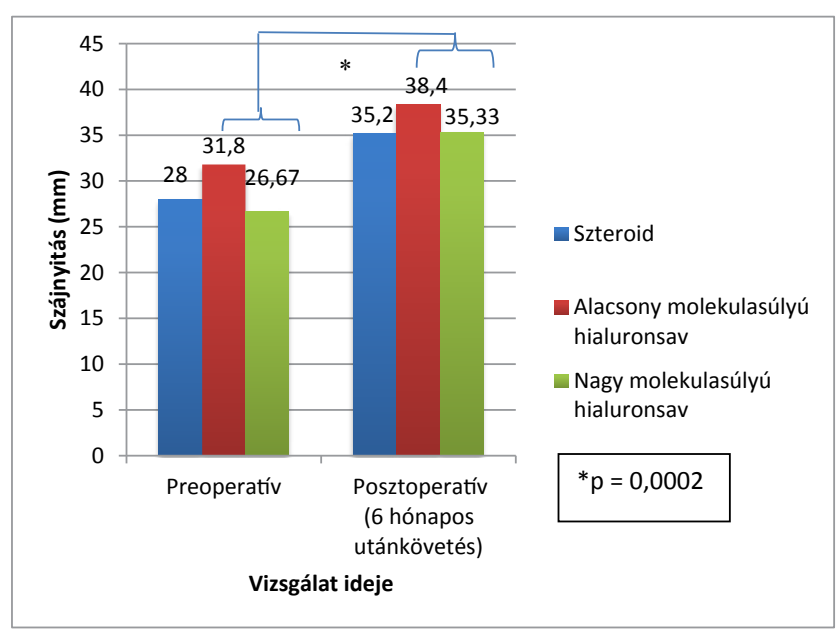

3. ábra $\quad$ A szájnyitás változása szteroidos és hialuronsavas kezelés hatá

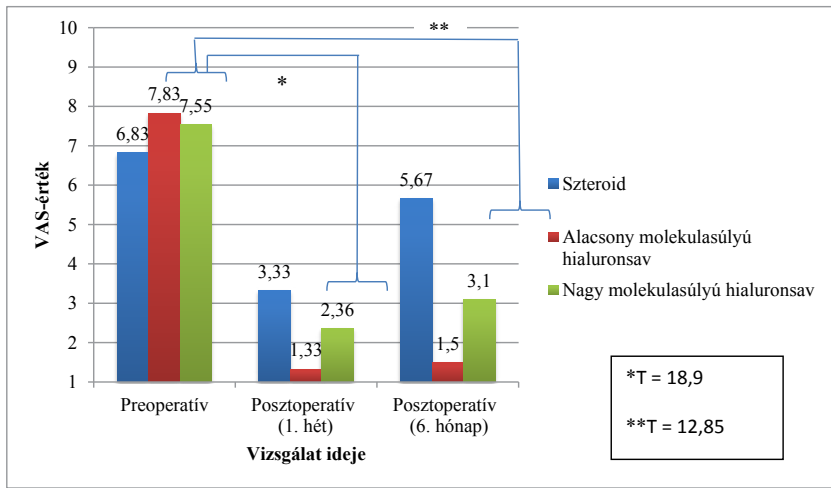

4. ábra $\quad$ A VAS-értékek változása szteroidos és hialuronsavas kezelés hatására.

VAS = Vizuális Analóg Skála

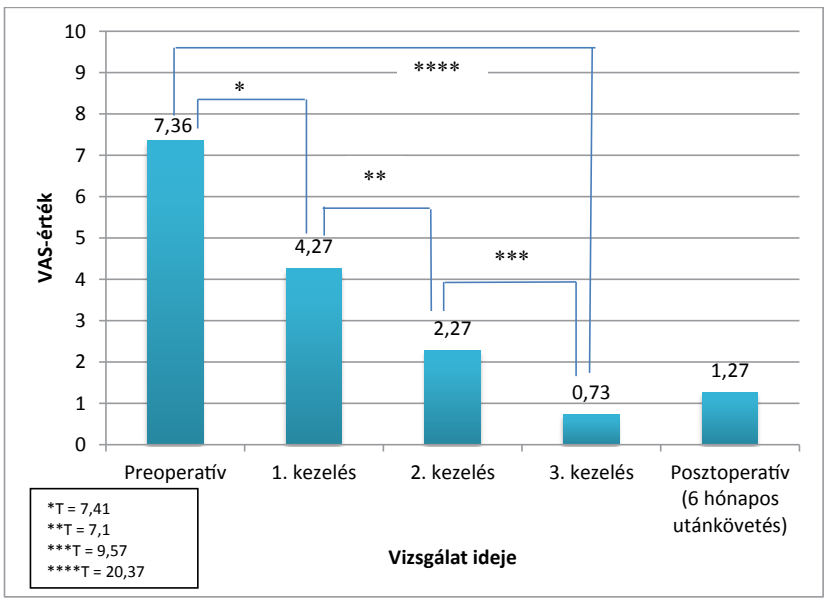

5. ábra

A fájdalomintenzitás változása a különböző kezelési fázisokban hialuronsavas terápia hatására

A hialuronsav alkalmazásakor a fájdalom csökkenése a kiindulási értékhez viszonyítva minden lépésben szignifikáns. A háromszori adagolás szignifikánsabban jobb eredményeket hozott az egyszeri és kétszeri alkalmazáshoz képest (5. ábra).

\section{Megbeszélés}

A hialuronsav a synovialis folyadék legfontosabb természetes alkotóeleme [2, 17]. Mechanikai hatása a lubrikáció, azaz nedvesítés folyamatán alapul, kenőanyagként csökkenti, mérsékli az ízületi felszínek, csontos struktúrák súrlódását, ezáltal azok kopását és a másodlagos öszszenövéseket az ízületi térben [17]. Metabolikus tulajdonságai közül a hialuronsav antiinflammatorikus hatása révén a gyulladásos mediátorok számát csökkenti, hozzájárulva ezzel az ízületi fájdalom enyhítéséhez, illetve anyagcsere-szabályozó szerepe révén segédkezik a discus és a porc avascularis részének táplálásában [17]. Habár óriási szerepe van az ízület lubrikációjában és anyagcseréjének szabályozásában, a pontos mechanizmus még nem teljesen tisztázott [12]. A korábban végzett vizsgálatokból formálódott a hialuronsav alkalmazásának két különböző változata: vagy önmagában, viscosupplementatio céljára, vagy sebészi beavatkozás kiegészítésére [2, 18]. Mindkét metódus célja a kóros tünetek enyhítése és a gyulladás csökkentése.

A temporomandibularis ízületi megbetegedések mögött az esetek nagy részében a kóros mozgások, ízületi terhelések és a károsodott ízületi felszín miatt változatos mértékủ krónikus gyulladásos jellegú folyamat áll fenn. A szteroid jól ismert erős hatású antiinflammatorikus szer. Az intraarticularis terápiában használatos kortikoszteroidok egyik legfontosabb ízületre gyakorolt hatása, hogy a gyulladás korai és késő́i manifesztációit egyaránt gátolják. Az akut gyulladásos területeken csökken a leukocyták migrációja és aktivitása; a krónikus gyulladásos területeken a mononukleáris sejtek aktivitása csökken, az erek proliferációja és a fibrosis mérséklődik. Gyulladásos mediátorokra gyakorolt hatásuk miatt csökken a citokinek hatása és termelődése [19]. Az intraarticularis szteroidos terápia protokollja az irodalomban változatos [2].

A temporomandibularis ízületi megbetegedések előfordulásának nembeli különbségeit többen vizsgálták. Európában a kórkép előfordulásának aránya férfiak és nők körében Helkimo kutatásai alapján 10 : 14\% [20], Szentpétery szerint 3,2:8,3\% [21]. Egyesek szerint a nők körében négyszer gyakoribb a betegség előfordulása, valamint háromszor gyakrabban fordulnak orvoshoz problémájukkal, mint a férfiak [22]. Az említett tendencia kutatásunkban is megmutatkozik: a betegek $90 \%$-a nő volt. Valószínűsíthető, hogy a kórkép prevalenciája és a kezelésre adott válasz egymással korrelál bizonyos nembeli különbségek (hormonháztartás, pszichoszociális és habituális tényező́k) miatt [22].

$\mathrm{Az}$ általános értelemben vett temporomandibularis ízületi elváltozások leginkább a fiatal és a középkorú felnőtteket érintik. Az átlagpopuláció 17-30 év közötti korosztálya produkál tüneteket a leggyakrabban, míg a páciensek közül leginkább a 20-40 év közöttiek érintettek $[23,24]$. A jelen tanulmányban az átlagéletkor 46 év, mely nem tér el jelentősen ezen átfogó kutatások eredményétól. 
A rágóízületi károsodás osztályozásakor nem veszik figyelembe a betegséget kiváltó okot $[6,15]$. Vizsgáltuk, hogy van-e összefüggés az anamnézisben felderíthető kiváltó tényezők és a kezelés eredményessége között. Úgy találtuk, hogy amennyiben már kialakult az elváltozás, a stádium nagysága és a kezelés mikéntje nincs összefüggésben a kórképet létrehozó okkal, természetesen a kiinduló konzervatív kezelési formáktól eltekintve.

Reumatológiai betegek kezelése során hazai, empirikus alapon bevett gyakorlat volt reumatológusok körében, hogy a súlyosabb eseteket szteroiddal, az enyhébb stádiumban lévőket hialuronsavval kezelték. Vizsgáltuk, hogy a magasabb és az alacsonyabb Wilkes-stádiummal rendelkezók között a hatóanyag, illetve a hialuronsav alkalmazásán belül a molekulasúly befolyásolja-e a kezelési eredményességet. A kétfajta molekulasúlyú hialuronsav közel azonos terápiás eredményt hozott, viszont nagyobb hatékonyság mutatkozott mindkettőnél a szteroiddal összehasonlítva (1. ábra). A hialuronsavval történő intraarticularis kezelés a magasabb fokú Wilkes-állapotokban eredményesebbnek bizonyult, mint az enyhébb fokozatú esetekben (2. ábra). Míg a reumatológusokhoz sokszor akut panaszokkal jönnek a betegek, ami mögött a legtöbbször az ízületi gyulladás akut fellángolása áll, s kezelésük során így a szteroid - fooleg a súlyosabb esetekben - hasznos, addig vizsgálatunkba az akut gyulladásban lévő ízületeket nem vettük be. Pácienseinknél a nagymértékű fájdalmat a krónikus gyulladásos folyamatok és a mozgáskorlátozottság okozhatja.

A hialuronsav nagyobb funkcióbeli javulást eredményező hatását tapasztaltuk a kortikoszteroidterápiával összehasonlítva, épp ellenkezőleg, mint ahogyan Kopp [25, 26] és Møystad [27] közléseiben láttuk. A szájnyitás milliméterben mért javulása csak a hialuronsavas kezelés hatására volt szignifikáns, de a kapott eredményeken az is látható, hogy mindkét módszer alkalmazásakor javult a betegek állapota a 6 hónapos utánkövetés során (3. ábra). Ennek oka lehet az utóbbi években használt, jelentősen magasabb molekulasúlyú hialuronsav-készítmények nagyobb hatékonysága. Látható a 3. ábrán, hogy a magasabb molekulasúlyú anyagnál nagyobb különbség mutatkozott a pre- és posztoperatív status között a szteroidos és az alacsony molekulasúlyú csoporthoz viszonyítva is.

Egy 2014-es tanulmányban a hialuronsav, a tenoxikám és a betametazon fájdalomcsökkentő hatását hasonlították össze, és a hialuronsav szignifikánsan jobb terápiás hatását tapasztalták a többi csoporthoz képest [28]. Kutatásunkban a hialuronsav önmagában szignifikánsan javított a panaszokon, a szteroidkezelés hatására kisebb mérvű javulást tapasztaltunk a fájdalom enyhülésében. A felmérés tehát azt mutatja, hogy igen jelentős csökkenés következett be a fájdalom intenzitásában, illetve hogy azok a páciensek, akik hialuronsav-injekciót kaptak, jobb terápiás eredményt mutattak. Bjørnland vizsgálati eredményeihez hasonlóan tehát a hialuronsav nagyobb mér- vư fájdalomredukáló hatását figyeltük meg a szteroidhoz képest [29].

Egy 2013-as áttekintő vizsgálat azt a következtetést vonta le, hogy a hialuronsav és a kortikoszteroid rövid és középtávon hasonló eredményeket hoz, míg hosszabb távon a hialuronsav jobb eredményeket produkál [30]. Ettől eltérően úgy találtuk, hogy már a korai posztoperatív időszakban is szignifikáns a különbség. Az irodalomban közölt adatoktól való eltérést mi a módszerünkre vezetjük vissza: mint az 5 ábrán látható, a háromszor adott hialuronsav jelentősen hatékonyabb, mint azt egyszer alkalmazva. A hialuronsavas terápiában mindhárom kezelést követően szignifikánsan csökkent a betegek fájdalma. Feltételezzük, hogy az egyszeri alkalmazás után mért rövid és középtávú eredmények jóval közelebb állnának a szteroidéihoz, mint ahogyan más közleményben is találjuk. A 6 hónapos kontroll után kismérvü visszaesés tapasztalható, azonban a tüneteknek ez a rosszabbodása a háromszori alkalmazás után kialakult szignifikáns javulásból történik, így még ezt követően is szignifikánsan jobb értékeket mutat a kiinduláshoz képest. Miután a beadott hialuronsav rövid idő alatt lebomlik (az alacsonyabb molekulasúlyú 24 óra, a magasabb néhány nap alatt), a többször adott szer nagyobb hatékonyságát máshol kell keresnünk, habár az irodalomban fellelhető ajánlások meglehetősen változatosak [31]. A háromszor adott hialuronsav véleményünk szerint az endogén hialuronsav képzésének fokozásán keresztül éri el tartósabb és nagyobb mértékű hatásosságát, amit így nem csupán egyszer, hanem több lépésben is indukálunk. Egyesek javasolják a hialuronsav többszöri (akár ötszöri) alkalmazását, annak az egyszeri kezeléshez viszonyított eredményesebb hatása miatt [32, 33]. Ugyanakkor megfontolandó az invazív kezelések számát a lehetőség szerinti legkevesebbre szorítani, hogy az esetleges szövődményeket minimalizálhassuk. Eredményeinkben a háromszori adagolás után mért értékek a normális tartományban vagy ahhoz igen közel helyezkedtek el, így ennek tükrében nem látjuk indokoltnak a hialuronsav többszöri alkalmazását.

A korábban alkalmazott kisebb molekulasúlyú hialuronsav helyett újabban a nagy molekulasúlyú formulát alkalmazzák, nagyobb fájdalomcsökkentő hatása miatt $[33,34]$. Vizsgálatunkban a két változat között egyik paraméter tekintetében sem kaptunk szignifikáns különbséget, hasonlóképpen ahogy egy 2012-es tanulmányban is találták [32]. Ugyan betegeinknél a magasabb molekulasúlyú hialuronsav esetében a szájnyitás javulásában elért eredmény tendenciózusan jobbnak bizonyult (3. ábra), a VAS skálán mért eredmények tekintetében a magasabb molekulasúlyú anyag nem mutatkozott hatásosabbnak. Az 1 hetes kontroll-fájdalomérték a preoperatív értékhez képest mindkét molekulasúly esetén jobb, a recidíva pedig kisebb volt, mint a szteroid alkalmazásakor kapott eredmény (4. ábra). Feltételezzük, hogy nagyobb esetszámú vizsgálattal a két molekulasúly hatékonyságában további eltérést találhatunk majd. 
Anyagi megfontolásból a hialuronsav drágább a kortikoszteroidhoz képest, de a betegek életminőségének javulása és a rendszeresen szedett fájdalomcsillapítók elhagyása jelentősen csökkenti a költségeket.

Az irodalomban fellelhető tanulmányok közül csupán nagyon kevés számolt be intraarticularis injekciót követő komplikációról. Iida és mtsai hialuronsav-injekciót követően tapasztalták eróziók kifejlődését az eminentia articularison, Wenneberg és mtsai pedig egy beteg esetében figyelték meg a csontos destrukció progresszióját kortikoszteroidinjekció után $[35,36]$.

\section{Következtetés}

Betegeinknél az intraarticularisan alkalmazott kortikoszteroid, valamint a hialuronsav csökkentette a temporomandibularis ízület belső károsodásának tüneteit. A két készítményt összehasonlítva megállapíthatjuk, hogy a hialuronsav mind a fájdalom enyhítésében, mind pedig a szájnyitás fokozásának tekintetében szignifikánsan jobb eredményeket hozott. Az adagolás szempontjából a háromszori alkalmazás, a kétféle molekulasúlyú hialuronsav közül pedig a magasabb molekulatömegú anyag nyújtott ugyan nem szignifikáns, de eredményesebb terápiás hatást. Eredményeink alátámasztásához azonban további vizsgálatok szükségesek, nagyobb esetszámmal.

Anyagi támogatás: A közlemény megírása, illetve a kapcsolódó kutatómunka anyagi támogatásban nem részesült.

Szerzôi munkamegosztás: V. M., V. Sz.: A vizsgálat lefolytatása. S. P., H. P.: A betegek organizációja. R. L., Cs. K. B.: Statisztikai elemzések. A cikk végleges változatát valamennyi szerző jóváhagyta.

Érdekeltségek: A szerzőknek nincsenek érdekeltségeik.

\section{Irodalom}

[1] Luther F, Layton S, McDonald F. Orthodontics for treating temporomandibular joint (TMJ) disorders. Cochrane Database Syst Rev. 2010; 7: CD006541.

[2] Mountziaris PM, Kramer PR, Mikos AG. Emerging intra-articular drug delivery systems for the temporomandibular joint. Methods 2009; 47: 134-140.

[3] Szentpétery A, Fazekas A, Mari A. An epidemiologic study of mandibular dysfunction dependence on different variables. Community Dent Oral Epidemiol. 1987; 15: 164-168.

[4] Jerolimov V. Temporomandibular disorders and orofacial pain. Rad 504 Med Sci. 2009; 33: 53-77.

[5] Trumpy LG, Eriksson J, Lyberg T. Internal derangement of the temporomandibular joint: correlation of arthrographic imaging with surgical findings. Int J Oral Maxillofac Surg. 1997; 26: 327-330.

[6] Laskin DM, Abubaker AO. (eds.) Decision making in oral and maxillofacial surgery. Quintessence Publishing Co. Inc., Batavia, IL, 2007; pp. 153-184.
[7] Neeli AS, Umarani M, Kotrashetti SM, et al. Arthrocentesis for the treatment of internal derangement of the temporomandibular joint. J Maxillofac Oral Surg. 2010; 9: 350-354.

[8] Costen JB. A syndrome of ear and sinus symptoms dependent upon disturbed function of the temporo-mandibular joint. Ann Otol Rhinol Laryngol. 1934; 43: 1-15.

[9] American Society of Temporomandibular Joint Surgeons. Guidelines for diagnosis and management of disorders involving the temporomandibular joint and related musculoskeletal structures. Cranio 2003; 21: 68-76.

[10] Alpaslan GH, Alpaslan C. Efficacy of temporomandibular joint arthrocentesis with and without injection of sodium hyaluronate in treatment of internal derangements. J Oral Maxillofac Surg. 2001; 59: 613-618.

[11] Hepguler S, Akkoc YS, Pehlivan M, et al. The efficacy of intraarticular sodium hyaluronate in patients with reducing displaced disk of the temporomandibular joint. J Oral Rehabil. 2002; 29: 80-86.

[12] Yeung RW, Chow RL, Samman N, et al. Short-term therapeutic outcome of intra-articular high molecular weight hyaluronic acid injection for nonreducing disk displacement of the temporomandibular joint. Oral Surg Oral Med Oral Pathol Oral Radiol Endod. 2006; 102: 453-461.

[13] Basterzi Y, Sari A, Demirkan F, et al. Intraarticular hyaluronic acid injection for the treatment of reducing and nonreducing disk displacement of the temporomandibular joint. Ann Plast Surg. 2009; 62: 265-267.

[14] Sato S, Kawamura H. Changes in condylar mobility and radiographic alterations after treatment in patients with non-reducing disc displacement of the temporomandibular joint. Dentomaxillofac Radiol. 2006; 35: 289-294.

[15] Wilkes CH. Internal derangements of the temporomandibular joint. Pathological variations. Arch Otolaryngol Head Neck Surg. 1989; 115: 469-477.

[16] Toller PA. Use and misuse of intra-articular corticosteroids in treatment of temporomandibular joint pain. Proc Roy Soc Med. 1977; 70: 461-463.

[17] Kim CH, Lee BJ, Yoon J, et al. Therapeutic effect of hyaluronic acid on experimental osteoarthrosis of ovine temporomandibular joint. J Vet Med Sci. 2001; 63: 1083-1089.

[18] Alpaslan C, Bilgihan A, Alpaslan GH, et al. Effect of arthrocentesis and sodium hyaluronate injection on nitrite, nitrate, and thiobarbituric acid-reactive substance levels in the synovial fluid. Oral Surg Oral Med Oral Pathol Oral Radiol Endod. 2000; 89: 686-690.

[19] Szilvássy Z, Timár J. Adrenal cortex hormones and antagonists. In: Gyires K, Fürst Zs. (eds.) Pharmacology. [Mellékvesekéreghormonok és antagonistáik. In: Gyires K, Fürst Zs. (szerk.) Farmakológia.] Medicina Könyvkiadó, Budapest, 2007; pp. 717718. [Hungarian]

[20] Helkimo M. Studies on function and dysfunction of the masticatory system: IV. Age and sex distribution of symptoms of dysfunction of the masticatory system in Lapps in the north of Finland. Acta Odontol Scand. 1974; 32: 255-267.

[21] Szentpétery A, Huhn E, Fazekas A. Prevalence of mandibular dysfunction in an urban population in Hungary. Community Dent Oral Epidemiol. 1986; 14: 177-180.

[22] Poveda Roda R, Bagan JV, Díaz Fernández JM, et al. Review of temporomandibular joint pathology. Part I: classification, epidemiology and risk factors. Med Oral Patol Oral Cir Bucal 2007; 12: E292-E298.

[23] Wright EF, North SL. Management and treatment of temporomandibular disorders: a clinical perspective. J Man Manip Ther. 2009; 17: 247-254.

[24] Mazzetto MO, Rodrigues CA, Magril LV, et al. Severity of TMD related to age, sex and electromyographic analysis. Braz Dent J. 2014; 25: 54-58. 
[25] Kopp S, Akerman S, Nilner M. Short-term effects of intra-articular sodium hyaluronate, glucocorticoid, and saline injections on rheumatoid arthritis of the temporomandibular joint. J Craniomandib Disord. 1991; 5: 231-238.

[26] Kopp S, Carlsson GE, Haraldson T, et al. Long-term effect of intra-articular injections of sodium hyaluronate and corticosteroid on temporomandibular joint arthritis. J Oral Maxillofacial Surg. 1987; 45: 929-935.

[27] Møystad A, Mork-Knutsen BB, Bjørnland T. Injection of sodium hyaluronate compared to a corticosteroid in the treatment of patients with temporomandibular joint osteoarthritis: a CT evaluation. Oral Surg Oral Med Oral Pathol Oral Radiol Endod. 2008; 105: e53-e60.

[28] Gencer ZK, Özkiriş M, Okur A, et al. A comparative study on the impact of intra-articular injections of hyaluronic acid, tenoxicam and betametazon on the relief of temporomandibular joint disorder complaints. J Craniomaxillofac Surg. 2014; 42: 1117-1121.

[29] Bjørnland T, Gjaerum AA, Møystad A. Osteoarthritis of the temporomandibular joint: an evaluation of the effects and complications of corticosteroid injection compared with injection with sodium hyaluronate. J Oral Rehabil. 2007; 34: 583-589.

[30] Machado E, Bonotto D, Cunali PA. Intra-articular injections with corticosteroids and sodium hyaluronate for treating temporomandibular joint disorders: a systematic review. Dental Press J Orthod. 2013; 18: 128-133.

[31] Temporomandibular Joint Disorder. Premera. Medical Policy 2.01.21. Available from 2018. https://www.premera.com/ medicalpolicies/ 2.01.21.pdf [accessed: March 27, 2018.].
[32] Guarda-Nardini L, Cadorin C, Frizziero A, et al. Comparison of 2 hyaluronic acid drugs for the treatment of temporomandibular joint osteoarthritis. J Oral Maxillofac Surg. 2012; 70: 25222530.

[33] Abate M, Salini V. Hyaluronic acid in the treatment of osteoarthritis: What is new. In: Chen Q. (ed.) Osteoarthritis - diagnosis, treatment and surgery. IntechOpen, London, 2012; pp. 101122. Available from: http://www.intechopen.com/books/osteoarthritis-diagnosis-treatment-and-surgery/hyaluronicacid-inthe-treatment-of-osteoarthritis-what-is-new

[34] Wobig M, Bach G, Beks P, et al. The role of elastoviscosity in the efficacy of viscosupplementation for osteoarthritis of the knee: a comparison of hylan G-F 20 and a lower-molecular-weight hyaluronan. Clin Ther. 1999; 21: 1549-1562.

[35] Iida K, Kurita K, Tange K, et al. Necrosis of the articular tubercle after repeated injections of sodium hyaluronate in the temporomandibular joint: a case report. Int J Oral Maxillofac Surg. 1998; 27: $278-279$

[36] Wenneberg B, Kopp S, Gröndahl HG. Long-term effect of intraarticular injections of a glucocorticosteroid into the TMJ: a clinical and radiographic 8-year follow-up. J Craniomandib Disord. 1991; 5: 11-18.

(Vingender Szonja dr., Budapest, Árpád út 90-92. II/35., 1042 e-mail: vszonja@gmail.com)

\title{
Szabadgyökös reakciók klinikai vonatkozásai konferencia
}

A Magyar Szabadgyök-Kutató Társaság, a Semmelweis Egyetem Népegészségtani Intézete, a Debreceni Egyetem, Általános Orvostudományi Kar, a Magyar Természettudományi Társulat Tudománytörténeti Szakosztálya, az MTA Művelődéstörténeti Osztályközi Bizottság Élettudományok-története Munkabizottsága, az MTA Debreceni Akadémiai Bizottság, a MOT Fogászattörténeti Köre közös rendezvénye

\author{
2018. október 9. (kedd) 10 órakor \\ a Semmelweis Egyetem NET konferencia termében \\ (1089 Budapest, Nagyvárad tér 4. - 21. emelet). \\ A konferencia szervezői: \\ Prof. Dr. Blázovics Anna, Prof. Dr. Balla József, Prof. Dr. Forrai Judit \\ Regisztrálás: \\ e-mail: blazovics.anna@pharma.semmelweis-univ.hu
}

A részvétel ingyenes.

A cikk a Creative Commons Attribution-NonCommercial 4.0 International License (https://creativecommons.org/licenses/by-nc/4.0) feltételei szerint publikált Open Access közlemény, melynek szellemében a cikk nem kereskedelmi célból bármilyen médiumban szabadon felhasználható, megosztható és újraközölhető, feltéve, hogy az eredeti szerző és a közlés helye, illetve a CC License linkje és az esetlegesen végrehajtott módosítások feltüntetésre kerülnek. 